\title{
Indications of vascular endothelial cell dysfunction in systemic lupus erythematosus
}

\author{
M A BYRON,$^{14} \mathrm{M} \mathrm{J}$ ALLINGTON ${ }^{2} \mathrm{H}$ M CHAPEL ${ }^{3}$ A G MOWAT, ${ }^{4}$ \\ AND S A CEDERHOLM-WILLIAMS ${ }^{1}$.
}

From the IFibrinolysis Research Group, Nuffield Department of Obstetrics and Gynaecology, the ${ }^{2}$ Department of Haematology and the ${ }^{3}$ Department of Immunopathology, John Radcliffe Hospital, Headington, Oxford; and the ${ }^{4}$ Rheumatology Department, Nuffield Orthopaedic Centre, Oxford

SUMMARY Fibrinolytic and other factors have been measured in 73 patients with systemic lupus erythematosus or related conditions to determine whether clinical thrombosis, a common feature of these disorders, is associated with defective fibrinolysis. Twenty five of $72(35 \%)$ patients, compared with two of $22(9 \%)$ controls, showed a low level of plasminogen activator activity in response to venous occlusion, suggesting decreased fibrinolytic potential. In addition, mean plasma levels of von Willebrand factor antigen and fibronectin were markedly raised in the patients (mean (SD) $384 \cdot 5$ (277)\% and 727 (436) mg/l respectively) compared with healthy controls $(100(50) \%$ and $306(65) \mathrm{mg} / \mathrm{l})$. These data suggest a degree of endothelial cell dysfunction. No clear correlation was found between a history of thrombosis and any plasma factor measured, except for prolongation of clotting tests suggestive of the 'lupus anticoagulant'.

Key words: fibrinolysis, von Willebrand factor antigen, fibronectin.

Thrombosis is a well recognised feature of systemic lupus erythematosus (SLE). Both clinically detected arterial or venous thrombosis and low grade coagulation activation manifest by features such as glomerular thrombi and fibrin deposition in lupus nephritis have been described. ${ }^{1}{ }^{2}$ One factor already identified in association with thrombosis is the presence of the lupus anticoagulant, an antiphospholipid antibody which interferes with in vitro coagulation tests. ${ }^{13}$ The mechanism whereby this antibody predisposes to thrombosis is unknown, though it may block conversion of arachidonic acid to prostacyclin $\left(\mathrm{PGI}_{2}\right)$, a potent inhibitor of platelet aggregation. ${ }^{4}$

Under normal physiological conditions activation of coagulation automatically stimulates the release of plasminogen activator (PA) from the vascular endothelium. 5 Plasminogen activator is the major regulator of fibrinolysis and prevents unwanted fibrin deposition. The potential of the fibrinolytic system can be assessed by inducing venous occlusion in an arm and assaying plasminogen activator

Accepted for publication 24 April 1987.

Correspondence to $\mathrm{Dr} \mathrm{M}$ A Byron, Nuffield Department of Obstetrics and Gynaecology, John Radcliffe Hospital, Oxford OX3 9DU. activity, which normally increases six- to eightfold over resting levels. 'Poor responders' to venous occlusion may be identified, who frequently show a tendency towards fibrin deposition. ${ }^{6}$ Such a defect has been implicated in recurrent venous thrombosis, postphlebitic syndrome, coronary artery disease, and diabetic microangiopathy, ${ }^{7-9}$ and in some reports is associated with release of excessive amounts of PA inhibitor, which is also secreted by the endothelium. ${ }^{10}$ This present study was designed to assess the fibrinolytic system in patients with SLE.

\section{Patients and methods}

Seventy three patients with a clinical diagnosis of SLE or mixed connective tissue disease were identified from laboratory results and hospital records in several departments. Sixty eight patients (63 women, five men) had a diagnosis of SLE based on multisystem disease with serological features. Of these, $62(91 \%)$ satisfied the revised criteria for the diagnosis of SLE, the other six fulfilling three criteria. ${ }^{11}$ The other five patients (three women, two men) had a diagnosis of mixed connective tissue disease based on clinical features of an overlap syndrome, with the presence of antibodies to 
ribonucleoprotein. The mean (SD) age of the patients studied was $42.7(14.5)$ years, with a mean (SD) disease duration of $9 \cdot 2(7 \cdot 3)$ years. Each patient was examined and their notes reviewed.

Eleven patients were not receiving any therapy at the time of the study, 41 were taking corticosteroids, and 20 were taking cytotoxic drugs. Nineteen patients were receiving non-steroidal antiinflammatory drugs, usually naproxen, and two were taking low dose aspirin ( $300 \mathrm{mg}$ twice weekly). A variety of other drugs were used by some patients, most frequently diuretics (13 patients) and $\beta$ blockers (eight patients).

In addition to assays of fibrinolytic proteins, haematological, biochemical, and serological tests were performed. Healthy subjects drawn from laboratory and secretarial staff were examined to obtain control data.

Plasminogen activator activity was assayed in venous blood samples taken after 20 minutes of supine rest and after 10 minutes of venous occlusion at $80 \mathrm{mmHg} .{ }^{12}$ Blood was anticoagulated with one tenth volume $0 \cdot 1 \mathrm{M}$ trisodium citrate, then cooled on ice and centrifuged at $2000 \mathrm{~g}\left(4^{\circ} \mathrm{C}\right)$ for 10 minutes. Euglobulin fractions were obtained by addition of $9.5 \mathrm{ml}$ of cold acetic acid $(0.014 \%)$ to 0.5 $\mathrm{ml}$ plasma. After 15 minutes on ice the samples were spun at $2000 \mathrm{~g}$ for 10 minutes, the supernatants discarded, and the precipitates redissolved in $0.5 \mathrm{ml}$ of $50 \mathrm{mM} \mathrm{NaCl} / 27.6 \mathrm{mM}$ sodium barbitone $/ \mathrm{HCl}$ buffer, $\mathrm{pH} 7 \cdot 4$. Plasminogen activator activity was assayed by applying $50 \mu \mathrm{l}$ euglobulin fractions (in duplicate) to fibrin plates within 45 minutes of drawing the blood. Fibrin plates $(9 \mathrm{~cm}$ diameter) were prepared using bovine fibrinogen $(10 \mathrm{ml}, 2$

Table 1 Plasma proteins related to fibrinolysis in patients with SLE† and in healthy controls

\begin{tabular}{|c|c|c|}
\hline $\begin{array}{l}\text { Plasma } \\
\text { proteins }\end{array}$ & $\begin{array}{l}S L E \\
\text { mean }(S D) \\
(n)\end{array}$ & $\begin{array}{l}\text { Healthy controls } \\
\text { mean }(S D) \\
(n)\end{array}$ \\
\hline Fibrinogen $(\mathrm{g} / \mathrm{l})$ & $\begin{array}{l}3 \cdot 7(1 \cdot 0) \\
(66)\end{array}$ & $\begin{array}{l}3 \cdot 1(0 \cdot 5)^{*} \\
(32)\end{array}$ \\
\hline Plasminogen $(\mathrm{g} / \mathrm{l})$ & $\begin{array}{l}0.207(0.066) \\
(67)\end{array}$ & $\begin{array}{l}0.148(0.034)^{*} \\
(32)\end{array}$ \\
\hline$\alpha_{2}$ Macroglobulin $(\mathrm{g} / \mathrm{l})$ & $\begin{array}{l}2.939(1.014) \\
(59)\end{array}$ & $\begin{array}{l}2.23(0.52)^{*} \\
(32)\end{array}$ \\
\hline$\alpha_{2}$ Antiplasmin $(\mathrm{g} / \mathrm{l})$ & $\begin{array}{l}0 \cdot 666(0.226) \\
(59)\end{array}$ & $\begin{array}{l}0 \cdot 70(0 \cdot 14) \\
(32)\end{array}$ \\
\hline Antithrombin III $(\mathrm{g} / \mathrm{l})$ & $\begin{array}{l}0 \cdot 349(0.077) \\
(68)\end{array}$ & $\begin{array}{l}0.285(0.046)^{*} \\
(32)\end{array}$ \\
\hline$\alpha_{1}$ Antitrypsin (g/l) & $\begin{array}{l}2 \cdot 117(0.548) \\
(39)\end{array}$ & $\begin{array}{l}1.63(0.26)^{*} \\
(30)\end{array}$ \\
\hline
\end{tabular}

${ }^{*} \mathrm{p}<0.001$ (Student's $t$ test).

†Not all the patients underwent all the tests.
Table 2 Plasma levels of endothelial cell derived proteins in patients with SLE and in controls

\begin{tabular}{lll}
\hline & $\begin{array}{l}\text { SLE } \\
\text { mean }(S D) \\
(n)\end{array}$ & $\begin{array}{l}\text { Healthy controls } \\
\text { mean }(S D) \\
(n)\end{array}$ \\
\hline Fibronectin (mg/l) & $\begin{array}{l}727(436) \\
(45)\end{array}$ & $\begin{array}{l}306(65) \\
(32)\end{array}$ \\
$\begin{array}{l}\text { von Willebrand } \\
\text { factor antigen (\%) }\end{array}$ & $\begin{array}{l}384 \cdot 5(277) \\
(71)\end{array}$ & $\begin{array}{l}100(50)^{*} \\
(32)\end{array}$ \\
$\begin{array}{l}\text { Plasminogen activator } \\
\text { (CTA units/ml) }\end{array}$ & $\begin{array}{l}0 \cdot 17(0 \cdot 16) \\
1 \cdot 1(1 \cdot 2)\end{array}$ & $\begin{array}{l}0 \cdot 15(0 \cdot 11) \\
0 \cdot 95(0 \cdot 88) \\
\text { baseline } \\
\text { after occlusion }\end{array}$ \\
& $(72) \dagger$ & $(22)$ \\
\hline
\end{tabular}

${ }^{*} \mathrm{p}<0.001$ (Student's $t$ test).

tOne patient not tested.

$\mathrm{mg} / \mathrm{ml}$ ) in $0.15 \mathrm{M} \mathrm{NaCl}$ and clotted with $50 \mu \mathrm{l}$ of 50 units $/ \mathrm{ml}$ thrombin. The plates were incubated af $37^{\circ} \mathrm{C}$ for 17 hours and the lysis areas converted to Committee for Thrombolytic Activity (CTA) units by reference to a urokinase dilution curve. ${ }^{13}$

Plasma samples obtained before venous occlusion were also stored at $-20^{\circ} \mathrm{C}$ for the assay of fibrinogen, plasminogen, $\alpha_{2}$ macroglobulin, and $\&_{2}$ antiplasmin by radial immunodiffusion, ${ }^{14} \alpha_{1}$ a trypsin by nephelometry using a Beckman IE్ analytical system, antithrombin III by chromogen assay, ${ }^{15}$ fibronectin by radioimmunoassay (Alling ton and Govier, in preparation), and von Wille brand factor antigen by rocket immunoelectro $-\widetilde{D}$ phoresis. ${ }^{16}$ All antibodies used were prepared by the research group with the exception of anti-factor VIIIS antibody (Hoechst Pharmaceuticals, Hounslow, London, UK).

The kaolin clotting time (KCT) was used as a screening test for coagulation abnormalities. Thiš was carried out by incubating plasma $(100 \mu \mathrm{l})$ witho kaolin $(100 \mu \mathrm{l}, 5 \mathrm{mg} / \mathrm{ml})$ for three minutes at $37^{\circ} \mathrm{C} \frac{3}{2}$. after which $0.15 \mathrm{M} \mathrm{NaCl}(100 \mu \mathrm{l})$ and $0.025 \mathrm{M}$ $\mathrm{CaCl}_{2}(100 \mu \mathrm{l})$ were added and the clotting time measured. Mixing experiments were not performed.윽

Statistical analysis was performed using Student's $t$ test and $\chi^{2}$ test with Yates's correction.

\section{Results}

LABORATORY RESULTS

Table 1 shows the mean plasma values for fibri nogen, plasminogen, $\alpha_{2}$ macroglobulin, $\alpha_{2}$ antiplaso min, antithrombin III, and $\alpha_{1}$ antitrypsin in patients with SLE compared with healthy controls. The patients showed significantly higher values? $(p<0.001)$ for all of these factors except $\alpha_{2}$ antiplas 0 min. Plasma values of proteins secreted by the. endothelium are shown in Table 2. Plasma fib 
ronectin and von Willebrand factor antigen were both greatly raised in the patients $(p<0.001)$, but the mean levels of plasminogen activator activity both before and after venous occlusion were not significantly different in patients and controls. Fig. 1 shows the frequency distribution of the response to venous occlusion. Poor response was here defined as failure to demonstrate PA activity $>0.3 \mathrm{CTA} \mathrm{U} / \mathrm{ml}$ in response to venous occlusion. ${ }^{9}$ Twenty five of 72 $(35 \%)$ patients were poor responders, compared with two of $22(9 \%)$ controls $\left(\chi^{2}=4 \cdot 2, p<0.05\right)$.

When the results for plasma factors in SLE responders were compared with those for poor responders (Table 3) no significant differences were found between mean values, though the poor responders showed a tendency towards greater abnormality of the proteins secreted by the endothelium. Similar comparisons of plasma factors between patients with or without a history of thrombosis, or patients with or without prolonged coagulation, showed no differences.

The mean value (SD) of the KCT for controls was 62 (10) seconds and values of 83 seconds or longer were considered abnormal. Twenty five of $60(42 \%)$ patients had a prolonged KCT. One additional patient was receiving warfarin therapy for thrombotic problems and a previously diagnosed lupus anticoagulant.

CLINICAL CORRELATIONS

Twenty four patients $(33 \%)$ had a past history of venous or arterial thrombosis. Thirty eight per cent

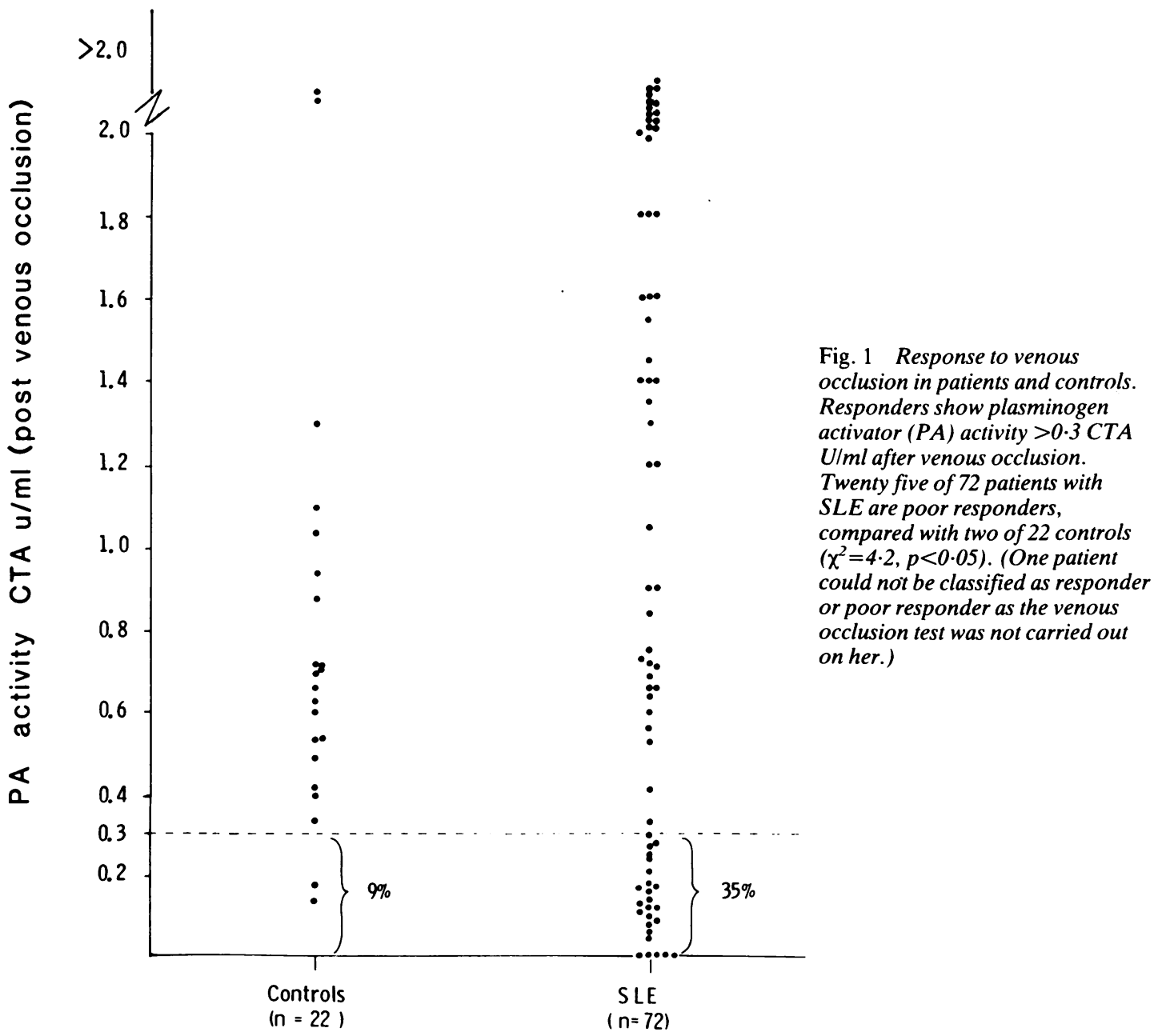


Table 3 Results for patients with SLE: responders and poor responders to venous occlusion*

\begin{tabular}{|c|c|c|}
\hline & $\begin{array}{l}\text { Responders (47) } \\
\text { mean }(S D) \\
(n)\end{array}$ & $\begin{array}{l}\text { Poor responders }(25) \\
\text { mean }(S D) \\
(n)\end{array}$ \\
\hline Fibrinogen $(\mathrm{g} / \mathrm{l})$ & $\begin{array}{l}3 \cdot 7(1 \cdot 1) \\
(42)\end{array}$ & $\begin{array}{l}3.78(0 \cdot 73) \\
(23)\end{array}$ \\
\hline Plasminogen $(g / l)$ & $\begin{array}{l}0 \cdot 206(0 \cdot 063) \\
(43)\end{array}$ & $\begin{array}{l}0 \cdot 207(0 \cdot 073) \\
(24)\end{array}$ \\
\hline$\alpha_{2}$ Macroglobulin $(\mathrm{g} / \mathrm{l})$ & $\begin{array}{l}2 \cdot 88(1 \cdot 21) \\
(37)\end{array}$ & $\begin{array}{l}2 \cdot 95(0 \cdot 82) \\
(22)\end{array}$ \\
\hline$\alpha_{2}$ Antiplasmin $(\mathrm{g} / \mathrm{l})$ & $\begin{array}{l}0 \cdot 678(0 \cdot 260) \\
(37)\end{array}$ & $\begin{array}{l}0 \cdot 645(0 \cdot 153) \\
(22)\end{array}$ \\
\hline Antithrombin III (g/l) & $\begin{array}{l}0 \cdot 349(0 \cdot 066) \\
(44)\end{array}$ & $\begin{array}{l}0 \cdot 348(0 \cdot 095) \\
(24)\end{array}$ \\
\hline$\alpha_{1}$ Antitrypsin $(\mathrm{g} / \mathrm{l})$ & $\begin{array}{l}2 \cdot 239(0 \cdot 544) \\
(23)\end{array}$ & $\begin{array}{l}1.943(0 \cdot 522) \\
(16)\end{array}$ \\
\hline Fibronectin (g/l) & $\begin{array}{l}0 \cdot 644(0 \cdot 278) \\
(30)\end{array}$ & $\begin{array}{l}0 \cdot 892(0 \cdot 627) \\
(15)\end{array}$ \\
\hline $\begin{array}{l}\text { von Willebrand } \\
\text { factor antigen }(\%)\end{array}$ & $\begin{array}{l}365(247) \\
(46)\end{array}$ & $\begin{array}{l}420(328) \\
(25)\end{array}$ \\
\hline
\end{tabular}

${ }^{*}$ One patient could not be classified as responder or poor responder as the venous occlusion test was not carried out on her.

of poor responders to venous occlusion had a history of thrombosis compared with $32 \%$ of responders, whereas $33 \%$ of patients with a prolonged KCT had a history of thrombosis compared with $15 \%$ of those without $\left(p<0.02, \chi^{2}\right.$ test). There was no correlation between response to venous occlusion and prolongation of KCT, age, disease duration, or drug therapy.

\section{Discussion}

The pathogenesis of thrombosis in SLE is multifactorial. ${ }^{1}$ Vascular endothelium contributes to prevention of fibrin deposition and thrombosis by secretion of plasminogen activator, the major regulator of fibrinolysis and its specific inhibitor. In this study the mean plasma levels of the fibrinolytic proteins were generally raised in the patient group (Table 1), though remaining within the physiological ranges for these proteins. These modestly raised levels probably reflect an acute phase response. For plasminogen and antithrombin III, a deficiency rather than an excess is associated with thrombosis. The finding of normal plasma levels of the fibrinolytic inhibitor $\alpha_{2}$ antiplasmin is in contrast with the study of Glas-Greenwalt et al, where high levels were found in patients with SLE. ${ }^{17}$

In a study of 28 patients with SLE Angles-Cano and coworkers found that fibrinolytic potential, as assessed by euglobulin lysis times before and after venous occlusion, was reduced in $16(57 \%)$ patients. ${ }^{18}$ In our study plasminogen activator activ- ity in response to venous occlusion was assessed more directly by applying euglobulin precipitates tow. bovine fibrin plates. No differences were found: between mean plasma values for plasminogen acti - vator activity before or after venous occlusion for either patients with SLE or controls. Analysis of the frequency of response to this stress test, however $\overline{\bar{D}}$ allowed division of the patients into two groups $-\frac{\mathbb{Q}}{2}$ those with a poor response to venous occlusion (postes PA activity $<0.3$ CTA units $/ \mathrm{ml}$ ) and those with a good response. Thirty five per cent of the patients and $9 \%$ of the controls were poor responders. Poor response to venous occlusion has been found in patient groups where thrombosis or fibrin deposi tion are well recognised complications, ${ }^{78}$ and in some patients this finding is related to increased? levels of plasminogen activator inhibitor rather than $\vec{p}$ to diminished plasminogen activator release from ${ }_{\perp}$ the endothelium. ${ }^{10}$ In our patients poor response to venous occlusion did not correlate with a history of thrombosis, age, disease duration, or drug therapy $\vec{\overrightarrow{ }}$ but this group did tend to show the more severe endothelial protein abnormalities (Table 3). Nö correlation was found between poor response tô venous occlusion and prolonged coagulation.

Other proteins secreted by the endothelium we्্ुळ also found in abnormally high levels in our patient group (Table 2). Like Angles-Cano et al, ${ }^{18}$ we foug raised levels of von Willebrand factor antigen Although it is not clear whether these high levels have a procoagulant effect, raised levels are found iñ other conditions where angiopathy is seen. ${ }^{19} \mathrm{Simi} \Omega$ larly, plasma fibronectin levels were raised. Fib $\overrightarrow{0}$ ronectin, a glycoprotein present in plasma and oven cell surfaces, is secreted by endothelium and rises in? response to venous occlusion in diabetics. ${ }^{9} 20$ High levels may reflect endothelial damage as fibronectim is produced by blood vessels in response to injury, ${ }^{2} \sqrt{2}$ and may contribute to thrombosis by affecting adhesion of blood cells to the endothelial surface. Levels of von Willebrand factor antigen and fib? ronectin did not correlate with a past history of thrombosis, or prolonged coagulation in oub patients.

An association between clinical thrombosis and the presence of the circulating lupus anticoagulant has been described by a number of researchers. ${ }^{1}$ ( The lupus anticoagulant is an antibody directes. against phospholipid determinants, ${ }^{23}$ and interfères. with in vitro coagulation tests. When the thrombo plastin (the platelet phospholipid substitute) is removed from the clotting test the sensitivity of detection of the anticoagulant increases, though its presence should be confirmed by mixing experiments. $^{24}$ In this study, using the KCT as 9 screening test, 25 patients showed prolonge 
coagulation. It is likely that this abnormality was due to the lupus anticoagulant in most patients as other causes of prolonged clotting are much more uncommon. ${ }^{1}$ It has been suggested that this antibody binds to the phospholipid of endothelial cell walls and disturbs arachidonic acid metabolism to prostacyclin $\left(\mathrm{PGI}_{2}\right)$, the potent inhibitor of platelet aggregation. ${ }^{4}$ Prolonged coagulation correlated with a past history of thrombosis in our patients but was unrelated to fibrinolytic potential, plasma von Willebrand factor antigen, and fibronectin, other indicators of endothelial function.

In conclusion, raised plasma levels of the fibrinolytic proteins are found in patients with SLE, but these are of little clinical significance. Evidence of endothelial dysfunction is suggested by markedly raised levels of von Willebrand factor antigen and fibronectin. A poor response in plasminogen activator activity to venous occlusion did not identify patients with clinical thrombotic problems. A past history of thrombosis in these patients did not correlate with any plasma factor measured, except prolongation of coagulation, suggesting the presence of the lupus anticoagulant. These findings do suggest endothelial cell dysfunction, which may contribute to microvascular disease in these patients.

The cause of this endothelial cell defect is at present unknown but it is possible that autoantibodies similar to the lupus anticoagulant may react with endothelial membrane determinants causing dysfunction that promotes low grade coagulopathy and fibrin deposition.

We would like to acknowledge Mrs S N Copper and Mrs A Rhodes for their excellent technical assistance. MAB was supported by a grant from the Arthritis and Rheumatism Council, UK.

\section{References}

1 Byron M A. The clotting defect in SLE. Clin Rheum Dis 1982; 8: $137-51$.

2 Kant K S, Pollak V E, Weiss M A, Glueck H I, Miller M A, Hess E V. Glomerular thrombosis in systemic lupus erythematosus: prevalence and significance. Medicine (Baltimore) 1981; 60: $71-85$.

3 Boey M L, Colaco C B, Gharavi A E, Elkon K B, Loizou S, Hughes G R V. Thrombosis in systemis lupus erythematosus: striking association with the presence of circulating lupus anticoagulant. $\mathrm{Br}$ Med $J$ 1983; 287: 1021-3.

4 Carreras L O, Defreyn G, Machin S J, et al. Arterial thrombosis, intrauterine death and 'lupus' anticoagulant; detection of immunoglobulin interfering with prostacyclin formation. Lancet 1981; i: 244-6.

5 Collen D. On the regulation and control of fibrinolysis. Thromb Haemost 1980; 43: 77-89.
6 Nilsson I M. Phenformin and ethylestranol in recurrent venous thrombosis. In: Davidson J F, Samama M M, Desmoyers P C, eds. Progress in chemical fibrinolysis and thrombolysis. Vol 1. New York: Raven Press, 1975; 1-12.

7 O'Conner N J T, Cederholm-Williams S A, Fletcher E W, Allington M J, Sharp A A. Significance of idiopathic deep venous thrombosis. Postgrad Med J 1984; 60: 35-7.

8 O’Conner N J T, Cederholm-Williams S A, Copper S, Cotter L. Hypercoagulability and coronary artery disease. Br Heart $\mathrm{J}$ 1984; 52: 614-6.

9 Haitas B, Barnes A J, Cederholm-Williams S A, Moore J, Shogry M E C, Turner R C. Abnormal endothelial release of fibrinolytic activity and fibronectin in diabetic microangiopathy. Diabetologia 1984; 27: 493-6.

10 Nilsson I M, Ljungner $H$, Tengborn L. Two different mechanisms in patients with venous thrombosis and defective fibrinolysis: low concentrations of plasminogen activator or increased concentrations of plasminogen activator inhibitor. $\mathrm{Br}$ Med $\mathrm{J}$ 1985; 290: 1453-6.

11 Tan E M, Cohen A S, Fries J G, et al. The 1982 revised criteria for the classification of systemic lupus erythematosus. Arthritis Rheum 1982; 25: 1271-7.

12 Robertson B R, Pandolfi M, Nilsson I M. Fibrinolytic capacity in healthy volunteers at different ages as standardised by venous occlusion of arms and legs. Acta Med Scand 1972; 191: 199-202.

13 Cederholm-Williams S A, Haitus B, Dornan T L, Turner R C Abnormal release of vascular plasminogen activator associated with diabetic microangiopathy. In: Jespersen J, Kluft C, Korsgaard O, eds Clinical aspects of fibrinolysis and thromboly. sis. Esberg, Denmark: South Jutland University Press, 1983. 321-35.

14 Mancini G, Carbonara A O, Heremans J F. Immunochemical quantitation of antigens by single radial immunodiffusion. Immunochemistry 1965; 2: 235-40.

15 Cederholm-Williams S A. Automated assay of antithrombins. Ann Clin Biochem 1980: 17: 183-4.

16 Laurell C B. Quantitative estimation of proteins by electrophoresis in agarose gel containing antibodies. Ann Biochem 1966; 15: 45-51.

17 Glas-Greenwalt P, Kant K S, Allen C, Pollak V E. Fibrinolysis in health and disease: severe abnormalities in systemic lupus erythematosus. J Lab Clin Med 1984; 104: 962-76.

18 Angles-Cano E, Sultan Y, Clauvel J-P. Predisposing factors to thrombosis in systemic lupus erythematosus. Possible relation to endothelial cell damage. $J$ Lab Clin Med 1979; 94: 312-22.

19 Dornan T L, Rhymes I L, Cederholm-Williams S A, et al. Plasma haemostatic factors and diabetic retinopathy. Eur J Clin Invest 1983; 13: 231-5.

20 Jaffe E A, Mosher D F. Synthesis of fibronectin by cultured human endothelial cells. J Exp Med 1978; 147: 1779-91.

21 Clark R A, Quinn J M, Winn M J, Lanigan J M, Dellepella P, Colvin $\mathrm{R} \mathrm{B}$. Fibronectin is produced by blood vessels in response to injury. $J$ Exp Med 1982; 156: 646-51.

22 Wautier J L, Paton R C, Wautier M P, et al. Increased adhesion of erythrocytes to endothelial cells in diabetes mellitus and its relation to vascular complications. $N$ Engl J Med 1981; 305: $237-42$.

23 Thiagarajan P, Shapiro S S, De Marco L. Monoclonal immunoglobulin M-lambda coagulation inhibitor with phospholipid specificity-mechanism of a lupus anticoagulant. J Clin Invest 1980; 66: 397-405.

24 Green D, Hougie C, Kazmier F L, et al. Report of the working party on acquired inhibitors of coagulation: studies of the 'lupus' anticoagulant. Thromb Haemost 1983; 49: 144-6. 